\title{
Synthesis of (-)-Kopsifoline A and (+)-Kopsifoline E
}

\author{
In-Soo Myeong, ${ }^{\ddagger}$ Nadide Hazal Avci, ${ }^{\ddagger}$ and Mohammad Movassaghi*
}

Department of Chemistry, Massachusetts Institute of Technology, Cambridge, Massachusetts 02139, United States

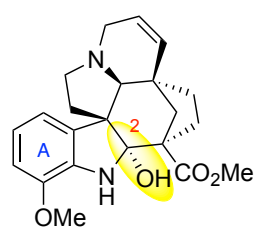

$(-)$-kopsifoline A

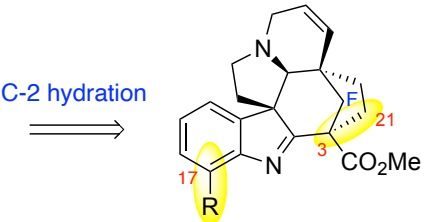

$\mathrm{R}=\mathrm{H}, \quad(-)$-kopsifoline D

ABSTRACT: We report the first total synthesis of (-)-kopsifoline A and (+)-kopsifoline E. Our synthetic strategy features a biogenetically inspired regioselective $\mathrm{C} 17$-functionalization of a versatile intermediate containing the pentacyclic core of aspidosperma alkaloids. While this advance intermediate provides (-)-kopsifoline D via C3-C21 bond formation, regioselective C17-boronation of its indoline substructure prior to introduction of the F-ring enables access to (-)-kopsifoline A and (+)-kopsifoline E. The vinylogous urethane substructure of the key intermediate was critical in C17-boronation over a competing C7-boronation in related indole derived substrates. After oxidation of the $\mathrm{C} 17-\mathrm{B}$ bond to introduce the $\mathrm{C} 17$-ether, the $\mathrm{C} 3-\mathrm{C} 21$ bond of the targets is secured under the Mitsunobu reaction conditions with the vinylogous urethane as the nucleophilic component.

The molecular complexity and the biological activity of the aspidosperma family of alkaloids continue to draw attention from the scientific community. ${ }^{1,2}$ A subset of these diverse alkaloids is the hexacyclic kopsia alkaloids that contain the characteristic pentacyclic aspidosperma core (Figure 1, rings A-E). ${ }^{3}$ Kopsifolines were first isolated from Malayan Kopsia species, K. fruticose (Ker) A. DC. and reported by Kam and Choo. ${ }^{4}$ While there are no reported syntheses of the C17-oxygenated (-)-kopsifoline A (1) and (+)-kopsifoline E (3), (-)-kopsifoline D (2) has been synthesized by the Boger and the Peng research groups in 2014 and 2019 , respectively. ${ }^{5}$ As an outgrowth of our studies of complex aspidosperma alkaloids, ${ }^{6}$ we describe the first total synthesis of (-)kopsifoline A (1) and (+)-kopsifoline E (3) via the late-stage C-17 functionalization of an advance intermediate that also affords rapid access to (-)-kopsifoline D (2). Specifically, we disclose the use of a vinylogous urethane substructure for regioselective C17functionalization of a common versatile intermediate and a dehydrative synthesis of the C3-C21 bond to afford the F-ring of the desired targets.

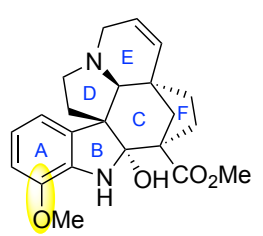

(-)-kopsifoline A (1)

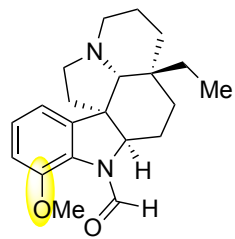

(-)-vallesine (4)

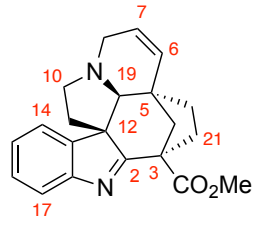

(-)-kopsifoline D (2)

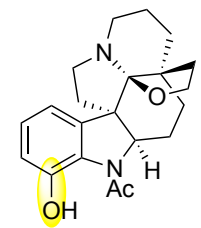

(+)-haplocidine (5)

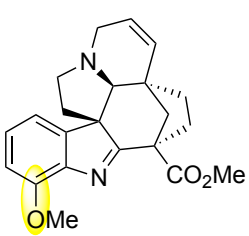

(+)-kopsifoline E (3)

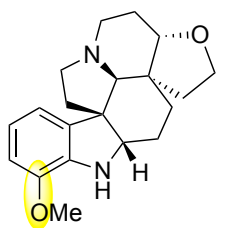

(-)-benine (6)

Figure 1. Representative kopsifolines and related C17-oxygenated aspidosperma alkaloids. 
Scheme 1. Retrosynthetic analysis.

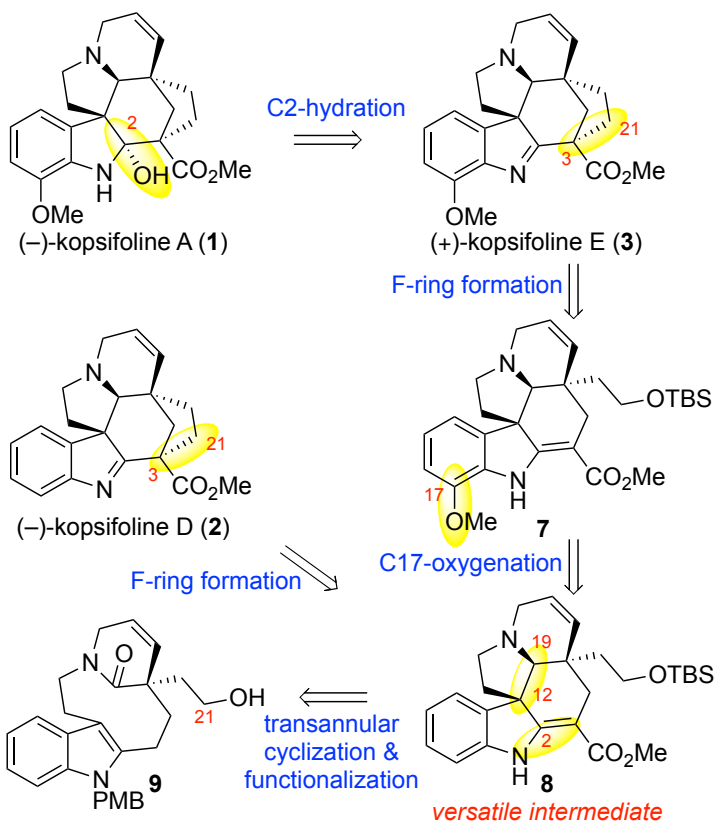

Our biogenetically inspired retrosynthetic analysis of (-)-kopsifoline A (1) and (+)-kopsifoline E (3) is illustrated in Scheme 1. We envisioned access to kopsifoline A (1) via hydration of the C2-imine of (+)-kopsifoline E (3). We anticipated the formation of the key $\mathrm{C} 3-\mathrm{C} 21$ bond, providing the F-ring of kopsifolines, via a net dehydrative cyclization of a C21-oxygenated aspidosperma derivative 8 with the $\mathrm{C} 2$-vinylogous urethane serving as the nucleophile. Recognizing that regioselective oxygenation of intermediate $\mathbf{8}$ would lead to kopsifoline A (1) and (+)-kopsifoline E (3), whereas F-ring formation from this versatile intermediate would give direct access to (-)-kopsifoline D (2) as well, we posited the potential utility of the C2-vinylogous urethane 8 to enable selective late-stage $\mathrm{C} 17$-functionalization. Informed by our earlier synthetic studies of complex aspidosperma alkaloids, we envisioned concise access to the versatile intermediate $\mathbf{8}$ from enantiomerically enriched and previously reported N1-para-methoxybenzyl (PMB) lactam 9. ${ }^{6 \mathrm{c}, 7}$

The use of the pentacyclic intermediate $\mathbf{8}$ as a common precursor to access kopsifoline alkaloids 1-3 required the development of reaction conditions for selective $\mathrm{C} 17$-functionalizaiton. Based on our prior success in late-stage C17-functionalization of complex substrates, ${ }^{6, c}$ we considered both $\mathrm{C} 17$-oxygentation ${ }^{8}$ and indirect $\mathrm{C} 17$-boronation. ${ }^{9}$ The absence of an N1-amide to direct C17acetoxylation, ${ }^{6 \mathrm{a}}$ and inspired by mild conditions for effective $\mathrm{C}-\mathrm{H}$ boronation of arenes, ${ }^{10}$ prompted us to consider selective $\mathrm{C} 17$ boronation to secure the $\mathrm{C} 17$-ether of alkaloids $\mathbf{1}$ and $\mathbf{3}$. Encouraged by our prior application of iridium-catalyzed boronation of complex indole substrates ${ }^{11}$ and the protocol we later developed for selective C7-boronation of substituted indoles, ${ }^{12,13}$ we began our studies with preparation of the desired key intermediate 8 from lactam 9 (Scheme 2).

Scheme 2. Synthesis of the advance intermediate 8.

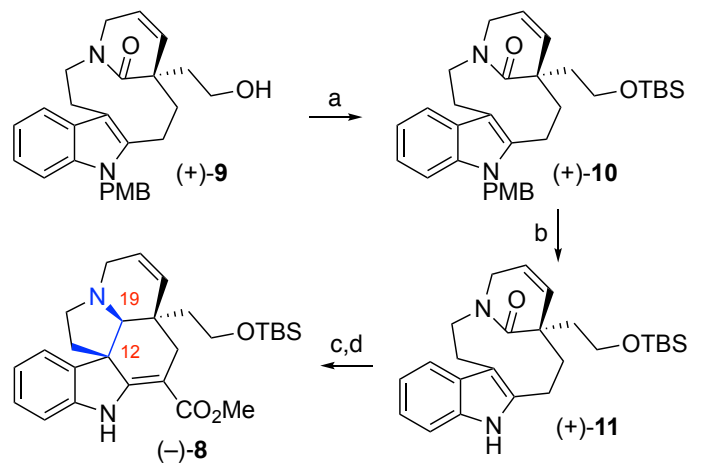

Reagents and conditions: (a) TBSCl, imidazole, DMAP, DMF, $23{ }^{\circ} \mathrm{C}, 2 \mathrm{~h}, 90 \%$; (b) Na, $\mathrm{NH}_{3}$ (liq.), THF $-78{ }^{\circ} \mathrm{C}, 1.5 \mathrm{~h}, 92 \%$; (c) DIBAL$\mathrm{H}$, THF, $0{ }^{\circ} \mathrm{C}, 1.5 \mathrm{~h}$; (d) $n$-BuLi, methyl cyanoformate, THF, $-78^{\circ} \mathrm{C}, 1 \mathrm{~h}, 80 \%$ (2 steps).

Our synthesis of the versatile intermediate $\mathbf{8}$ commenced by silylation of the readily available and enantiomerically enriched C21-alcohol $(+)-9^{6 c, 14}$ to give the silyl ether $(+)-10$ in $90 \%$ yield. Exposure of N1-PMB indole $(+)-10$ to Birch reduction conditions ${ }^{15}$ afforded the indole $(+)-\mathbf{1 1}$ in $92 \%$ yield. Treatment of lactam $(+)-\mathbf{1 1}$ with diisobutylaluminum hydride led to stereoselective 
transannular cyclization by formation of the $\mathrm{C} 12-\mathrm{C} 19$ bond, ${ }^{6 \mathrm{c}}$ and the resulting $\mathrm{C} 2$-imine was deprotonated and intercepted by methyl cyanoformate ${ }^{16}$ to afford vinylogous urethane $(-)-8$ in $80 \%$ yield. ${ }^{17}$

Equation 1. C17-Boronation of vinylogous urethane (-)-8.
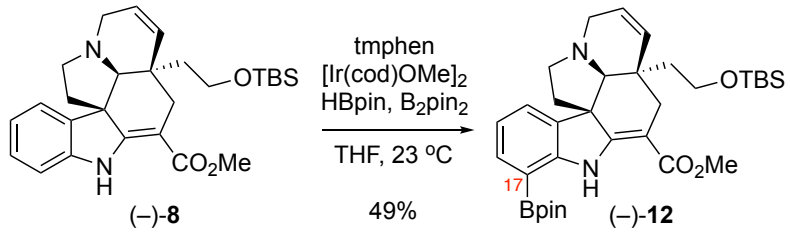

We next focused on development of a strategy for direct and selective C17-boronation of the vinylogous urethane (-)-8. After significant experimentation, we found that exposure of pentacycle (-)-8 to $(1,5$-cyclooctadiene)(methoxy)iridium(I) dimer $[\operatorname{Ir}(\operatorname{cod}) \mathrm{OMe}]_{2}(10 \mathrm{~mol} \%)^{10 \mathrm{c}}$ in the presence of 3,4,7,8-tetramethyl-1,10-phenanthroline (tmphen, 20 mol\%) along with stoichiometric pinacolborane (HBpin, 5 equiv) and bis(pinacolato)diboron $\left(\mathrm{B}_{2} \mathrm{pin}_{2}, 5\right.$ equiv) in THF at $23{ }^{\circ} \mathrm{C}$ for $20 \mathrm{~h}$ afforded the desired intermediate (-)-12 (eq. 1). The use of $\mathrm{B}_{2} \mathrm{pin}_{2}$ alone under the same conditions did not lead to boronation of pentacycle (-)-8. Similarly, while the use of HBpin alone under otherwise identical $[\operatorname{Ir}(\operatorname{cod}) \mathrm{OMe}]_{2}(10 \mathrm{~mol} \%)$, and tmphen $(20 \mathrm{~mol} \%)$ in $\mathrm{THF}$ at $23{ }^{\circ} \mathrm{C}$ for $20 \mathrm{~h}$ conditions led to only $12 \%$ yield of the product 12 along with recovery of the starting material (-)-8 (68\%), warming the reaction mixture $\left(60{ }^{\circ} \mathrm{C}\right)$ led to significant decomposition. Notably, the use of conditions we had previously applied to boronation of a complex indole ${ }^{6 \mathrm{c}}$ employing 4,4'-di-tert-butyl-2,2'-dipyridyl (dtbpy, $\left.20 \mathrm{~mol} \%\right)^{10 \mathrm{c}, 1}$ with HBpin (5 equiv) only returned the starting vinylogous urethane (-)-8. It is important to note that the C2-vinylogous urethane substructure of intermediate (-)-8 was particularly effective in allowing for selective $\mathrm{C} 17$-boronation.

\section{Equation 2. Boronation of indole 11.}
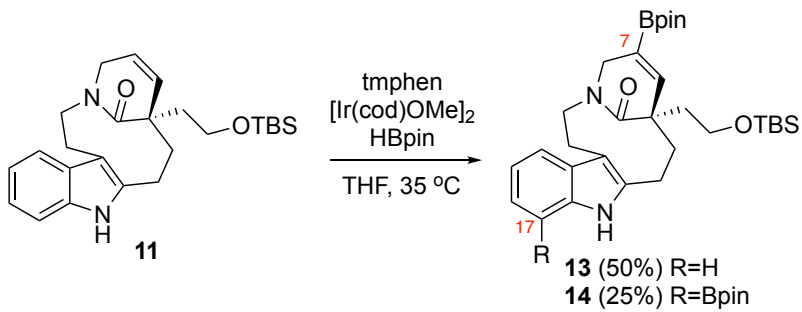

For comparison, in an earlier approach to kopsifolines, we examined the boronation of indole 11 (eq. 2), an indole similar to the substrate used successfully in our synthesis of (-)-vallesine (4) via late-stage C17-boronation. ${ }^{6 \mathrm{c}}$ However, we observed faster C7alkene boronation using substrate $\mathbf{1 1}$ as compared to the desired C17-boronation. It is expected that a combination of functional group directing, steric, and electronic factors contribute ${ }^{10 \mathrm{k}}$ to the observed regioselectivity in the boronation reaction of substrates $\mathbf{8}$ and 11 (eq. 1 and 2). Indeed, the variation of the electron density at N1, C7, and C17 are readily apparent by comparison of these substrates. ${ }^{14,18}$ We note that the conversion of lactam (+)-11 to pentacyclic vinylogous urethane $(-)-\mathbf{8}$, not only provides greater structural rigidity, but also leads to an increase in the electron density at both $\mathrm{N} 1$ and $\mathrm{C} 17$ relative to the alkene. ${ }^{13 \mathrm{~d}}$ Importantly, the optimal conditions described above (eq. 1) ${ }^{14}$ provided an effective means of accessing the desired C17-boronated urethane $(-)$-12 with minimal double boronation $(<2 \%)$ and no alkene boronation byproducts.

With a successful strategy for selective C17-boronation of vinylogous urethane (-)-8 in hand, we examined our projected approach for securing the F-ring via C3-C21 bond formation. ${ }^{5}$ Treatment of the pentacycle (-)-8 with tetra- $n$-butylammonium fluoride provided the C21-alcohol (-)-15 in 96\% yield (Scheme 3). Consistent with a biogenetically inspired late-stage dehydrative Fring formation, exposure of C21-alcohol (-)-15 to diisopropyl azodicarboxylate and triphenylphosphine afforded (-)-kopsifoline D (2) in 70\% yield. ${ }^{19}$ All spectroscopic data for our synthetic (-)-kopsifoline D (2) were consistent with literature reports. ${ }^{4 b, 5}$ The $^{23}$ optical rotation for alkaloid 2 (observed $[\alpha]_{\mathrm{D}}{ }^{25}=-87.9\left(c 0.10, \mathrm{CHCl}_{3}\right)$; lit. $[\alpha]_{\mathrm{D}}=-69\left({ }_{\mathrm{c}} 0.08, \mathrm{CHCl}_{3}\right),{ }^{5 \mathrm{a}}[\alpha]_{\mathrm{D}}{ }^{23}=-82(c 0.30$, $\left.\mathrm{CHCl}_{3}\right)^{5 \mathrm{~b}}$ ) was in agreement with literature values.

Scheme 3. Synthesis of (-)-kopsifoline D (2).

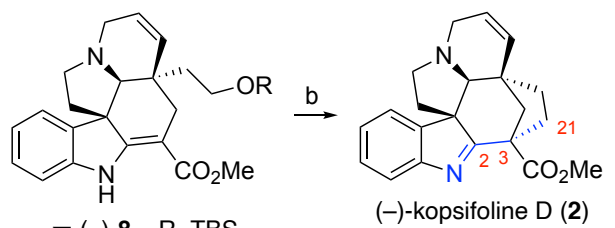

$$
a\left[\begin{array}{ll}
(-)-8, & R=T B S \\
-(-)-15, & R=H
\end{array}\right.
$$

(-)-kopsifoline D (2)

Reagents and conditions: (a) TBAF, THF, 0 to $23{ }^{\circ} \mathrm{C}, 5 \mathrm{~h}, 96 \%$; (b) diisopropyl azodicarboxylate, $\mathrm{PPh}_{3}, \mathrm{THF}, 23{ }^{\circ} \mathrm{C}, 8 \mathrm{~h}, 70 \%$. 
Scheme 4. Synthesis of (-)-kopsifoline A (1) and (+)-kopsifoline E (3).

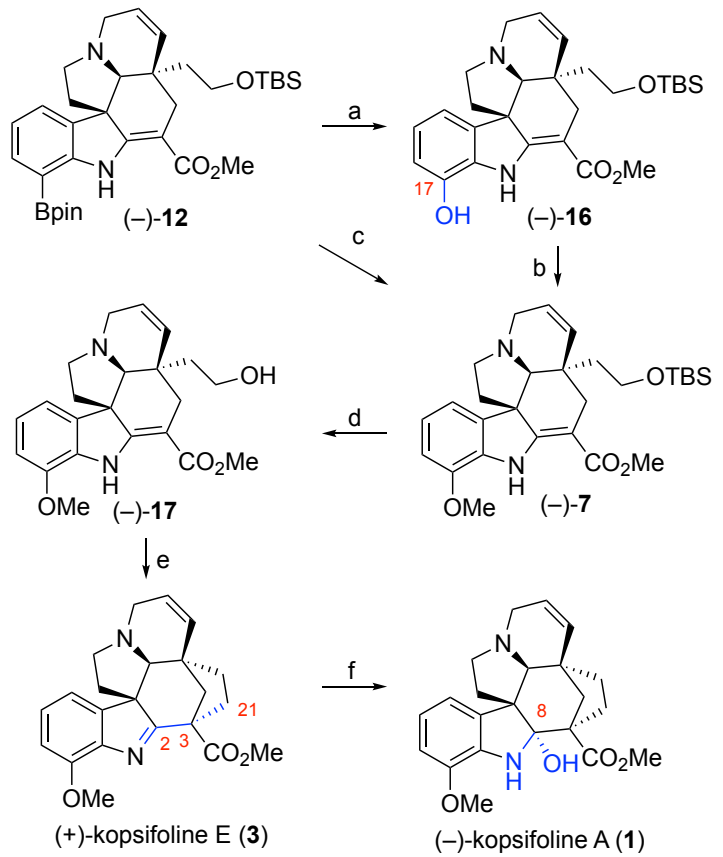

Reagents and conditions: (a) $\mathrm{Et}_{2} \mathrm{NOH}, \mathrm{MeOH}, 23{ }^{\circ} \mathrm{C}, 48 \mathrm{~h}, 64 \%$; (b) $\mathrm{Cs}_{2} \mathrm{CO}_{3}, \mathrm{MeI}$, Acetone, $23{ }^{\circ} \mathrm{C}, 1 \mathrm{~h}, 100 \%$; (c) $\mathrm{Cu}(\mathrm{OAc}){ }_{2}$, DMAP, $\mathrm{MeOH}, \mathrm{CH}_{2} \mathrm{Cl}_{2}, 23{ }^{\circ} \mathrm{C}, 48 \mathrm{~h}, 42 \%$; (d) TBAF, THF, 0 to $23{ }^{\circ} \mathrm{C}, 2.5 \mathrm{~h}, 80 \%$; (e) diisopropyl azodicarboxylate, $\mathrm{PPh}_{3}$, THF, $23{ }^{\circ} \mathrm{C}, 14$ h, $78 \%$; (f) $\mathrm{H}_{2} \mathrm{O}$, Formic acid, THF, $23{ }^{\circ} \mathrm{C}, 2$ h, $73 \%$.

Our concise synthesis of (-)-kopsifoline A (1) and (+)-kopsifoline E (3) is illustrated in Scheme 4. With rapid access to C17boronopentacycle (-)-12 via late-stage boronation of the versatile intermediate (-)-8 (eq.1), we examined two options for introduction of the required C17-ether. Treatment of aryl boronic ester (-)-12 with diethylhydroxylamine afforded the phenol (-)-16 in $64 \%$ yield. The selective $O$-methylation of phenol (-)-16 using methyl iodide and cesium carbonate quantitatively afforded the desired C17-methyl ether (-)-7. Alternatively, exposure of a solution of intermediate (-)-12 in dichloromethane-methanol to copper(II) acetate and 4-dimethylaminopyridine directly gave the C17-methyl ether (-)-7 in modest yield. ${ }^{131, m, 20}$ Unveiling the C21-alcohol afforded the pentacyclic alcohol (-)-17 in $80 \%$ yield. Sequential application of a bioinspired condensative F-ring cyclization conditions, as described in our synthesis of (-)-kopsifoline D (2, Scheme 3), provided (+)-kopsifoline E (3) in 78\% yield, which upon formic acid catalyzed C2-hydration yielded (-)-kopsifoline A (1) in 73\% yield. All spectroscopic data for our synthetic (+)kopsifoline E (3) and (-)-kopsifoline A (1) were consistent with the corresponding literature reports. ${ }^{4 b, 14}$ The optical rotation for synthetic (+)-kopsifoline $\mathrm{E}(3)$ (observed $[\alpha]_{\mathrm{D}}{ }^{25}=+44.3\left(c 0.07, \mathrm{CHCl}_{3}\right)$ and $[\alpha]_{\mathrm{D}}{ }^{25}=+65.1\left(c 0.07, \mathrm{CH}_{2} \mathrm{Cl}_{2}\right) ;$ lit. $[\alpha]_{\mathrm{D}}=+84(c 0.15$, $\left.\left.\mathrm{CHCl}_{3}\right)^{4 \mathrm{~b}}\right)^{14}$ and (-)-kopsifoline A (1) $\left([\alpha]_{\mathrm{D}}{ }^{25}=-11.7\left(c 0.10, \mathrm{CHCl}_{3}\right)\right.$; lit. $\left.[\alpha]_{\mathrm{D}}=-11\left(c 0.43, \mathrm{CHCl}_{3}\right)^{4 \mathrm{~b}}\right)$ were agreeable with reported values.

In summary, we describe the first total synthesis of (-)-kopsifoline A (1) and (+)-kopsifoline E (3). Our synthetic approach to these alkaloids is based on a biogenetically inspired regioselective C17-functionalization of an advance vinylogous urethane (-)-8. While F-ring synthesis from this intermediate gives (-)-kopsifoline D (2), regioselective C17-boronation allows for introduction of the A-ring methyl ether en route to $(+)$-kopsifoline E (3) and (-)-kopsifoline A (1). Notably, the C-ring vinylogous urethane of intermediate (-)-8 not only offers regioselective $\mathrm{C} 17$-functionalization, it also serves as a carbon-nucleophile in a condensative $\mathrm{F}$ ring synthesis under Mitsunobu reaction conditions.

\section{ASSOCIATED CONTENT}

The Supporting Information is available free of charge.

Experimental procedures, spectroscopic data, and copies of ${ }^{1} \mathrm{H}$, and ${ }^{13} \mathrm{C}$ NMR spectra (PDF)

\section{AUTHOR INFORMATION}

\section{Corresponding Author}

*movassag@mit.edu

\section{Author Contributions}

$\$$ These authors contributed equally. 
We are grateful for financial support by NIH-NIGMS (GM141963). We thank the NSF CCI Center for Selective C-H Functionalization (CHE-1700982) for supporting our boronation studies. I.-S.M. acknowledges a Yonsung postdoctoral fellowship.

\section{Notes}

The authors declare no competing financial interest.

\section{ACKNOWLEDGMENTS}

We thank Ms. Kristen M. Flynn, and Mr. Taylor Pinto for helpful discussions.

\section{REFERENCES}

(1) (a) Cordell, G. A. The Aspidosperma Alkaloids In The Alkaloids: Chemistry and Physiology; Manske, R. H. F., Rodrigo, R. G. A., Eds.; Academic Press: New York, 1979; Vol. 17, pp 199-384; (b) Saxton, J. E. Alkaloids of the aspidospermine group In The Alkaloids: Chemistry and Biology; Cordell, G. A., Ed.; Academic Press: San Diego, 1998; Vol. 51, pp 1-197; (c) O'Connor, S. E. Alkaloids In Comprehensive Natural Products II: Chemistry and Biology; Mander, L., Liu, H.-W., Eds.; Elsevier: Amsterdam, 2010; Vol. 1, pp 977-1007.

(2) (a) Saxton, J. E. Synthesis of the aspidosperma alkaloids In The Alkaloids: Chemistry and Biology; Cordell, G. A., Ed.; Academic Press: San Diego, 1998; Vol. 50, pp 343-376; (b) Lopchuk, J. M. Recent Advances in the Synthesis of Aspidosperma-type Alkaloids. Prog. Heterocycl. Chem. 2011, 23, 1-25.

(3) Kam, T.-S.; Lim, K.-H. Alkaloids of Kopsia In The Alkaloids: Chemistry and Biology; Cordell, G. A., Ed.; Elsevier: New York, 2008; Vol. 66, pp 1-111.

(4) (a) Kam, T.-S.; Choo, Y.-M. Kopsifolines A, B, and C, Indole Alkaloids with a Novel Hexacyclic Carbon Skeleton from Kopsia. Tetrahedron Lett. 2003, 44, 1317-1319; (b) Kam, T. S.; Choo, Y. M. Kopsifolines A-F: a New Structural Class of Monoterpenoid Indole Alkaloids from Kopsia. Helv. Chim. Acta 2004, 87, 991-998; (c) Kam, T.-S.; Choo, Y.-M. Venalstonine and Dioxokopsan Derivatives from Kopsia fruticosa. Phytochemistry 2004, 65, 2119-2122.

(5) (a) Lee, K.; Boger, D. L. Total Syntheses of (-)-Kopsifoline D and (-)-Deoxoapodine: Divergent Total Synthesis via Late-Stage Key Strategic Bond Formation. J. Am. Chem. Soc. 2014, 136, 3312-3317; (b) Zhou, Y.-G.; Wong, H. N. C.; Peng, X.-S. Total Syntheses of (-)-Deoxoapodine, (-)-Kopsifoline D, and (-)-Beninine. J. Org. Chem. 2019, 85, 967-976.

(6) (a) White, K. L.; Movassaghi, M. Concise Total Syntheses of (+)-Haplocidine and (+)-Haplocine via Late-Stage Oxidation of (+)Fendleridine Derivatives. J. Am. Chem. Soc. 2016, 138, 11383-11389; (b) Kang, T.; White, K. L.; Mann, T. J.; Hoveyda, A. H.; Movassaghi, M. Enantioselective Total Synthesis of (-) Deoxoapodine. Angew. Chem. Int. Ed. 2017, 56, 13857-13860; (c) Antropow, A. H.; Garcia, N. R.; White, K. L.; Movassaghi, M. Enantioselective Synthesis of (-)-Vallesine: Late-Stage C17-Oxidation via Complex Indole Boronation. Org. Lett. 2018, 20, 3647-3650.

(7) (a) Medley, J. W.; Movassaghi, M. A Concise and Versatile Double-Cyclization Strategy for the Highly Stereoselective Synthesis and Arylative Dimerization of Aspidosperma Alkaloids. Angew. Chem. Int. Ed. 2012, 51, 4572-4576; (b) Mewald, M.; Medley, J. W.; Movassaghi, M. Concise and Enantioselective Total Synthesis of (-)-Mehranine, (-)-Methylenebismehranine, and Related Aspidosperma Alkaloids. Angew. Chem. Int. Ed. 2014, 53, 11634-11639.

(8) (a) Tellitu, I.; Urrejola, A.; Serna, S.; Moreno, I.; Herrero, M. T.; Domínguez, E.; SanMartin, R.; Correa, A. On the Phenyliodine (III)-Bis (trifluoroacetate)-Mediated Olefin Amidohydroxylation Reaction. Eur. J. Org. Chem. 2007, 2007, 437-444; (b) Wang, G.-W.; Yuan, T.-T.; Wu, X.-L. Direct Ortho-Acetoxylation of Anilides via Palladium-Catalyzed $\mathrm{sp}^{2} \mathrm{C}-\mathrm{H}$ Bond Oxidative Activation. J. Org. Chem. 2008, 73, 4717-4720; (c) Wang, G.-W.; Yuan, T.-T. Palladium-Catalyzed Alkoxylation of N-Methoxybenzamides via Direct sp ${ }^{2}$ C-H Bond Activation. J. Org. Chem. 2010, 75, 476-479; (d) Jiang, T.-S.; Wang, G.-W. Palladium-Catalyzed ortho-Alkoxylation of Anilides via C-H Activation. J. Org. Chem. 2012, 77, 9504-9509; (e) Shan, G.; Yang, X.; Ma, L.; Rao, Y. Pd-Catalyzed C-H Oxygenation with TFA/TFAA: Expedient Access to Oxygen-Containing Heterocycles and Late-Stage Drug Modification. Angew. Chem. Int. Ed. 2012, 51, 13070-13074; (f) Yang, X.; Shan, G.; Rao, Y. Synthesis of 2-Aminophenols and Heterocycles by Ru-Catalyzed C-H Mono-and Dihydroxylation. Org. Lett. 2013, 15, 2334-2337; (g) Zhang, Z.-J.; Quan, X.-J.; Ren, Z.-H.; Wang, Y.-Y.; Guan, Z.-H. A Facile BPO-Mediated ortho-Hydroxylation and Benzoylation of N-Alkyl Anilines for Synthesis of 2-Benzamidophenols. Org. Lett. 2014, 16, $3292-3295$.

(9) (a) Mkhalid, I. A. I.; Barnard, J. H.; Marder, T. B.; Murphy, J. M.; Hartwig, J. F. C-H Activation for the Construction of C-B Bonds. Chem. Rev. 2010, 110, 890-931; (b) Hartwig, J. F. Regioselectivity of the Borylation of Alkanes and Arenes. Chem. Soc. Rev. 2011, 40, 1992-2002; (c) Ros, A.; Fernández, R.; Lassaletta, J. M. Functional Group Directed C-H Borylation. Chem. Soc. Rev. 2014, 43, 32293243; (d) Xu, L.; Wang, G.; Zhang, S.; Wang, H.; Wang, L.; Liu, L.; Jiao, J.; Li, P. Recent Advances in Catalytic C-H Borylation Reactions. Tetrahedron 2017, 73, 7123-7157.

(10) For representative reports of iridium-catalyzed boronations, see: (a) Cho, J.-Y.; Tse, M. K.; Holmes, D.; Maleczka, R. E.; Smith, M. R., III. Remarkably Selective Iridium Catalysts for the Elaboration of Aromatic C-H Bonds. Science 2002, 295, 305-308; (b) Ishiyama, T.; Takagi, J.; Ishida, K.; Miyaura, N.; Anastasi, N. R.; Hartwig, J. F. Mild Iridium-Catalyzed Borylation of Arenes. High Turnover Numbers, Room Temperature Reactions, and Isolation of a Potential Intermediate. J. Am. Chem. Soc. 2002, 124, 390-391; (c) Ishiyama, T.; Takagi, J.; Hartwig, J. F.; Miyaura, N. A Stoichiometric Aromatic C-H Borylation Catalyzed by Iridium (I)/2,2'-Bipyridine Complexes at Room Temperature. Angew. Chem. Int. Ed. 2002, 41, 3056-3058; (d) Tamura, H.; Yamazaki, H.; Sato, H.; Sakaki, S. Iridium-Catalyzed Borylation of Benzene with Diboron. Theoretical Elucidation of Catalytic Cycle Including Unusual Iridium (V) Intermediate. J. Am. Chem. Soc. 2003, 125, 16114-16126; (e) Boller, T. M.; Murphy, J. M.; Hapke, M.; Ishiyama, T.; Miyaura, N.; Hartwig, J. F. Mechanism of the Mild Functionalization of Arenes by Diboron Reagents Catalyzed by Iridium Complexes. Intermediacy and Chemistry of BipyridineLigated Iridium Trisboryl Complexes. J. Am. Chem. Soc. 2005, 127, 14263-14278; (f) Kawamorita, S.; Ohmiya, H.; Hara, K.; Fukuoka, A.; Sawamura, M. Directed Ortho Borylation of Functionalized Arenes Catalyzed by a Silica-Supported Compact Phosphine-Iridium System. J. Am. Chem. Soc. 2009, 131, 5058-5059; (g) Boebel, T. A.; Hartwig, J. F. Silyl-Directed, Iridium-Catalyzed ortho-Borylation of Arenes. A One-Pot ortho-Borylation of Phenols, Arylamines, and Alkylarenes. J. Am. Chem. Soc. 2008, 130, 7534-7535; (h) Ishiyama, T.; Isou, H.; Kikuchi, T.; Miyaura, N. Ortho-C-H borylation of benzoate esters with bis(pinacolato)diboron catalyzed by iridium-phosphine complexes. Chem. Commun. 2010, 46, 159-161; (i) Roosen, P. C.; Kallepalli, V. A.; Chattopadhyay, B.; Singleton, D. A.; Maleczka Jr, R. E.; Smith, 
M. R., III. Outer-Sphere Direction in Iridium C-H Borylation. J. Am. Chem. Soc. 2012, 134, 11350-11353; (j) Preshlock, S. M.; Ghaffari, B.; Maligres, P. E.; Krska, S. W.; Maleczka Jr, R. E.; Smith III, M. R. High-throughput Optimization of Ir-catalyzed C-H Borylation: a Tutorial for Practical Applications. J. Am. Chem. Soc. 2013, 135, 7572-7582; (k) Larsen, M. A.; Hartwig, J. F. Iridium-Catalyzed C-H Borylation of Heteroarenes: Scope, Regioselectivity, Application to Late-Stage Functionalization, and Mechanism. J. Am. Chem. Soc. 2014, 136, 4287-4299; (1) Green, A. G.; Liu, P.; Merlic, C. A.; Houk, K. Distortion/Interaction Analysis Reveals the Origins of Selectivities in Iridium-Catalyzed C-H Borylation of Substituted Arenes and 5-Membered Heterocycles. J. Am. Chem. Soc. 2014, 136, 4575-4583.

(11) (a) Han, S.; Movassaghi, M. Concise Total Synthesis and Stereochemical Revision of all (-)-Trigonoliimines. J. Am. Chem. Soc. 2011, 133, 10768-10771; (b) Kolundzic, F.; Noshi, M. N.; Tjandra, M.; Movassaghi, M.; Miller, S. J. Chemoselective and Enantioselective Oxidation of Indoles Employing Aspartyl Peptide Catalysts. J. Am. Chem. Soc. 2011, 133, 9104-9111; (c) Han, S.; Morrison, K. C.; Hergenrother, P. J.; Movassaghi, M. Total Synthesis, Stereochemical Assignment, and Biological Activity of All Known (-)-Trigonoliimines. J. Org. Chem. 2014, 79, 473-486.

(12) (a) Loach, R. P.; Fenton, O. S.; Amaike, K.; Siegel, D. S.; Ozkal, E.; Movassaghi, M. C7-Derivatization of C3-Alkylindoles Including Tryptophans and Tryptamines. J. Org. Chem. 2014, 79, 11254-11263; (b) Amaike, K.; Loach, R. P.; Movassaghi, M. Direct C7 Functionalization of Tryptophan. Synthesis of Methyl (S)-2-((tert-Butoxycarbonyl)amino)-3-(7-(4,4,5,5-tetramethyl-1,3,2-dioxaborolan-2yl)-1H-indol-3-yl) propanoate. Org. Synth. 2015, 92, 373-385; (c) Loach, R. P.; Fenton, O. S.; Movassaghi, M. Concise Total Synthesis of (+)-Asperazine, (+)-Pestalazine A, and (+)-iso-Pestalazine A. Structure Revision of (+)-Pestalazine A. J. Am. Chem. Soc. 2016, 138, 10571064.

(13) For representative reports of iridium-catalyzed indole boronations, see: (a) Takagi, J.; Sato, K.; Hartwig, J. F.; Ishiyama, T.; Miyaura, N. Iridium-Catalyzed C-H Coupling Reaction of Heteroaromatic Compounds with Bis(pinacolato)diboron: Regioselective Synthesis of Heteroarylboronates. Tetrahedron Lett. 2002, 43, 5649-5651; (b) Ishiyama, T.; Takagi, J.; Yonekawa, Y.; Hartwig, J. F.; Miyaura, N. Iridium-Catalyzed Direct Borylation of Five-Membered Heteroarenes by Bis(pinacolato)diboron: Regioselective, Stoichiometric, and Room Temperature Reactions. Adv. Synth. Catal. 2003, 345, 1103-1106; (c) Robbins, D. W.; Boebel, T. A.; Hartwig, J. F. IridiumCatalyzed, Silyl-Directed Borylation of Nitrogen-Containing Heterocycles. J. Am. Chem. Soc. 2010, 132, 4068-4069; (d) Paul, S.; Chotana, G. A.; Holmes, D.; Reichle, R. C.; Maleczka, R. E.; Smith, M. R., III. Ir-Catalyzed Functionalization of 2-Substituted Indoles at the 7-Position: Nitrogen-Directed Aromatic Borylation. J. Am. Chem. Soc. 2006, 128, 15552-15553; (e) Kallepalli, V. A.; Shi, F.; Paul, S.; Onyeozili, E. N.; Maleczka Jr, R. E.; Smith III, M. R. Boc Groups as Protectors and Directors for Ir-Catalyzed C- H Borylation of Heterocycles. J. Org. Chem. 2009, 74, 9199-9201; (f) Meyer, F.-M.; Liras, S.; Guzman-Perez, A.; Perreault, C.; Bian, J.; James, K. Functionalization of Aromatic Amino Acids via Direct $\mathrm{C}-\mathrm{H}$ Activation: Generation of Versatile Building Blocks for Accessing Novel Peptide Space. Org. Lett. 2010, 12, 3870-3873; (g) Liskey, C. W.; Hartwig, J. F. Borylation of Arenes with Bis(hexylene glycolato)diboron. Synthesis 2013, 45, 1837-1842; (h) Zhou, S.; Jia, Y. Total Synthesis of (-)-Goniomitine. Org. Lett. 2014, 16, 3416-3418; (i) Homer, J. A.; Sperry, J. A Short Synthesis of the Endogenous Plant Metabolite 7-Hydroxyoxindole-3-Acetic Acid (7-OH-OxIAA) Using Simultaneous C-H Borylations. Tetrahedron Lett. 2014, 55, 5798-5800; (j) Sadler, S. A.; Tajuddin, H.; Mkhalid, I. A.; Batsanov, A. S.; Albesa-Jove, D.; Cheung, M. S.; Maxwell, A. C.; Shukla, L.; Roberts, B.; Blakemore, D. C. Iridium-Catalyzed C-H Borylation of Pyridines. Org. Biomol. Chem. 2014, 12, 7318-7327; (k) Eastabrook, A. S.; Wang, C.; Davison, E. K.; Sperry, J. A Procedure for Transforming Indoles into Indolequinones. J. Org. Chem. 2015, 80, 1006-1017; (1) Feng, Y.; Holte, D.; Zoller, J.; Umemiya, S.; Simke, L. R.; Baran, P. S. Total Synthesis of Verruculogen and Fumitremorgin A Enabled by Ligand-Controlled C-H Borylation. J. Am. Chem. Soc. 2015, 137, 10160-10163; (m) Norseeda, K.; Gasser, V.; Sarpong, R. A Late-Stage Functionalization Approach to Derivatives of the Pyrano [3,2-a]Carbazole Natural Products. J. Org. Chem. 2019, 84, 5965-5973; (n) Bhowmik, S.; Galeta, J.; Havel, V.; Nelson, M.; Faouzi, A.; Bechand, B.; Ansonoff, M.; Fiala, T.; Hunkele, A.; Kruegel, A. C. Site Selective C-H Functionalization of Mitragyna Alkaloids Reveals a Molecular Switch for Tuning Opioid Receptor Signaling Efficacy. Nat. Commun. 2021, 12, 1-14; (o) Hoque, M. E.; Hassan, M. M. M.; Chattopadhyay, B. Remarkably Efficient Iridium Catalysts for Directed C (sp2)-H and C (sp3)-H Borylation of Diverse Classes of Substrates. J. Am. Chem. Soc. 2021, 143, 5022-5037.

(14) Please see the Supporting Information for details.

(15) Feng, P.; Fan, Y.; Xue, F.; Liu, W.; Li, S.; Shi, Y. An Approach to the Hexacyclic Skeleton of Trigonoliimines. Org. Lett. 2011, $13,5827-5829$.

(16) Mander, L. N.; Sethi, S. P. Regioselective Synthesis of $\beta$-Ketoesters from Lithium Enolates and Methyl Cyanoformate. Tetrahedron Lett. 1983, 24, 5425-5428.

(17) (a) Kozmin, S. A.; Iwama, T.; Huang, Y.; Rawal, V. H. An Efficient Approach to Aspidosperma Alkaloids via [4 + 2] Cycloadditions of Aminosiloxydienes: Stereocontrolled Total Synthesis of $( \pm)$-tabersonine. Gram-Scale Catalytic Asymmetric Syntheses of $(+)-$ Tabersonine and (+)-16-Methoxytabersonine. Asymmetric Syntheses of (+)-Aspidospermidine and (-)-Quebrachamine. J. Am. Chem. Soc. 2002, 124, 4628-4641; (b) Jones, S. B.; Simmons, B.; Mastracchio, A.; MacMillan, D. W. C. Collective Synthesis of Natural Products by Means of Organocascade Catalysis. Nature 2011, 475, 183-188.

(18) Structures optimized with MMFF followed by DFT at B3LYP level with 6-311+g(d,p) as basis set (Gaussian09, by Gaussian, Inc.) in gas phase.

(19) (a) Boger, D. L.; McKie, J. A.; Nishi, T.; Ogiku, T. Enantioselective Total Synthesis of (+)-Duocarmycin A, epi-(+)Duocarmycin A, and Their Unnatural Enantiomers. J. Am. Chem. Soc. 1996, 118, 2301-2302; (b) Giovenzana, G. B.; Sisti, M.; Palmisano, G. Pyrrolizidine Alkaloids. A Concise Entry to (-)-Pyrrolam A. Tetrahedron: Asymmetry 1997, 8, 515-518; (c) Clavel, C.; BarraganMontero, V.; Montero, J.-L. Chain Elongation of Primary Alcohols of Carbohydrates. Tetrahedron Lett. 2004, 45, 7465-7467; (d) Coppola, G. M. Cyclization of 4-Hydroxy-3-hydroxyalkylcarbostyrils Under Mitsunobu Conditions. Synth. Commun. 2004, 34, 3381-3387; (e) Hillier, M. C.; Desrosiers, J.-N.; Marcoux, J.-F.; Grabowski, E. J. Stereoselective Carbon-Carbon Bond Formation via the Mitsunobu Displacement of Chiral Secondary Benzylic Alcohols. Org. Lett. 2004, 6, 573-576; (f) Hillier, M. C.; Marcoux, J.-F.; Zhao, D.; Grabowski, E. J.; McKeown, A. E.; Tillyer, R. D. Stereoselective Formation of Carbon-Carbon Bonds via $\mathrm{S}_{\mathrm{N}} 2$-Displacement: Synthesis of Substituted Cycloalkyl[b]indoles. J. Org. Chem. 2005, 70, 8385-8394.

(20) For representative applications in synthesis, see: (a) Eastabrook, A. S.; Sperry, J. Synthetic Access to 3, 5, 7-Trisubstituted Indoles Enabled by Iridium-Catalyzed C-H Borylation. Synthesis 2017, 49, 4731-4737; (b) Park, J.; Chen, D. Y.-K. A DesymmetrizationBased Total Synthesis of Reserpine. Angew. Chem. Int. Ed. 2018, 57, 16152-16156; (c) Chen, P.; Yang, H.; Zhang, H.; Chen, W.; Zhang, Z.; Zhang, J.; Li, H.; Wang, X.; Xie, X.; She, X. Total Synthesis of (-)-Gardmultimine A. Org. Lett. 2020, 22, $2022-2025$. 